\title{
Individualization of treatment in non-small cell lung cancer
}

Nico van Zandwijk

Address: Bernie Banton Centre, University of Sydney, Hospital Road, Concord, 2139 NSW, Australia

Email: zwk@med.usyd.edu.au

FI000 Medicine Reports 2009, I:24 (doi: 10.34I0/MI-24)

The electronic version of this article is the complete one and can be found at: http://FI000.com/Reports/Medicine/content/I/24

\begin{abstract}
Two recently reported randomized studies discussed below are paving the way for personalized treatment approaches for patients with non-small cell lung cancer (NSCLC). Both studies show that accurate subclassification of NSCLC will become necessary to prescribe chemotherapy doublets and epidermal growth factor receptor tyrosine kinase inhibitors. It is expected that the practice of the last 30 years of lumping all NSCLC subtypes together will soon come to an end.
\end{abstract}

\section{Introduction and context}

Lung cancer is the leading cause of cancer death in the world and progress in the treatment of the different diseases under this heading has been modest in the last 25 years. The two most important reasons for the lack of progress are the fact that the majority of patients with lung cancer present with advanced (metastatic) disease and that responses to systemic therapy most frequently are partial and of relatively short duration. About $85 \%$ of all patients with lung cancer have 'non-small cell' histology, and international guidelines indicate that four cycles of so-called platinum doublet chemotherapy are standard. These guidelines do not address histology or which platinum doublet.

\section{Recent advances}

A recent study has shown that pemetrexed/cisplatin was superior to gemcitabine/cisplatin in two subgroups of patients with non-small cell lung cancer (NSCLC): adenocarcinoma and large cell carcinoma. The gemcitabine/cisplatin combination performed better in patients with squamous cell carcinoma [1]. This important observation (that is, the increased sensitivity to specific chemotherapeutic agents in subgroups of patients with NSCLC) has been confirmed recently by others $[2,3]$. The main target of pemetrexed is thymidylate synthase (TS). In NSCLC patients who underwent surgical resection, TS is expressed at a higher level in squamous cell carcinoma than in adenocarcinoma and this may well explain the better result of pemetrexed in adenocarcinoma.

These recent study results show that the oncological community now has the opportunity to leave the current practice of lumping different histologies together and to prescribe cytotoxic drugs on clinicopathological parameters. The art of selecting systemic therapy for NSCLC lies not only in knowing which drugs to use but also in the selection of subgroups of patients who are most likely to benefit from the treatment.

Another category of systemic agents for NSCLC is composed of oral tyrosine kinase inhibitors of the epidermal growth factor receptor (otherwise known as EGFR-TKIs). Two EGFR-TKIs, erlotinib and gefitinib, have been studied extensively in the last 6-7 years and were found to induce responses, improve symptoms, and in some instances to prolong survival in previously treated patients with NSCLC $[4,5]$. During early clinical development of the two drugs, it had become apparent that patients with adenocarcinoma and patients with little or no exposure to cigarette smoke had better responses to these two agents; moreover, Southeast Asian patients seemed to respond better [6].

In 2004, independent groups of investigators suggested that increased sensitivity to EGFR inhibitors was related to specific mutations in the EGFR domain $[7,8]$. 
Prospective studies studying the efficacy of erlotinib and gefitinib in patients with EGFR mutations seemed to confirm this hypothesis [9], and very recently a randomized study revealed that gefitinib performs better than chemotherapy in a preselected group of Asian patients with adenocarcinoma (light or never smokers) with an EGFR mutation, whereas patients without a mutation had a more favourable result on chemotherapy [10].

\section{Implications for clinical practice}

Thus, there are multiple indications for the abandonment of the common practice of the last three decades of offering the same treatment to all patients with NSCLC. The studies cited above provide enough evidence to start using histology and mutation status as criteria for patient selection. The practical consequence of that will be a decrease in popularity of the fine-needle aspiration technique for diagnosis. Most likely, a cytological diagnosis will not be firm enough to serve as the basis for treatment advice in the near future. It is also worth mentioning that the determination of EGFR mutation status is quite laborious and needs an experienced hand. Therefore, it is generally felt that this selection criterion is not easily accessible to all oncology units. Solutions such as the introduction of specific diagnostic kits for EGFR mutations are currently being investigated.

The selection of subgroups of patients with NSCLC for therapy is becoming increasingly important. It is equally important to identify patients who are not likely to respond or live longer as a result of therapy. This is especially relevant for treatments related with significant toxicity or for which the cost-benefit ratio of the treatment is likely to be extremely high. An individualized treatment approach is becoming an important issue in NSCLC.

\section{Abbreviations}

EGFR, epidermal growth factor receptor; NSCLC, nonsmall cell lung cancer; TKI, tyrosine kinase inhibitor; TS, thymidylate synthase.

\section{Competing interests}

The author declares that he has no competing interests.

\section{References}

I. Scagliotti GV, Parikh P, von Pawel J, Biesma B, Vansteenkiste J, Manegold C, Serwatowski P, Gatzemeier U, Digumarti R, Zukin M, Lee JS, Mellemgaard A, Park K, Patil S, Rolski J, Goksel T, de Marinis F, Simms L, Sugarman KP, Gandara D: Phase III study comparing cisplatin plus gemcitabine with cisplatin plus pemetrexed in chemotherapy-naive patients with advanced-stage non-smallcell lung cancer. J Clin Oncol 2008, 26:3543-5I.

\section{Changes Clinical Practice}

FI000 Factor 4.8 Must Read

Evaluated by Nico van Zandwijk 22 Aug 2008, Daniel Vorobiof with Keorapetse Mafafo 2 Dec 2008

2. Peterson P, Park K, Fosella F, Gatzemeier U, John W, Scagliotti G: Is pemetrexed more effective in adenocarcinoma and large cell lung cancer than in squamous cell carcinoma? A retrospective analysis of a phase III trial of pemetrexed vs docetaxel in previously treated patients with advanced nonsmall cell lung cancer (NSCLC). J Thorac Oncol 2007, 2:S85I.

3. Ciuleanu TE, Brodowicz T, Belani CP, Kim J, Krzakowski M, Laack E, Wu Y, Peterson P, Adachi S, Zielinski CC: Maintenance pemetrexed plus best supportive care (BSC) versus placebo plus BSC: A phase III study. J Clin Oncol 2008, ASCO Annual Meeting Proceedings, 26(May 20 Suppl):Abstract $801 \mathrm{I}$.

4. Fukuoka M, Yano S, Giaccone G, Tamura T, Nakagawa K, Douillard JY, Nishiwaki Y, Vansteenkiste J, Kudoh S, Rischin D, Eek R, Horai T, Noda K, Takata I, Smit E, Averbuch S, Macleod A, Feyereislova A, Dong RP, Baselga J: Multi-institutional randomized phase II trial of gefitinib for previously treated patients with advanced nonsmall-cell lung cancer (The IDEAL I Trial) [corrected]. J Clin Oncol 2003, 21:2237-46.

5. Shepherd FA, Rodrigues Pereira J, Ciuleanu T, Tan EH, Hirsh V, Thongprasert S, Campos D, Maoleekoonpiroj S, Smylie M, Martins R, van Kooten M, Dediu M, Findlay B, Tu D, Johnston D, Bezjak A, Clark G, Santabárbara P, Seymour L, National Cancer Institute of Canada Clinical Trials Group: Erlotinib in previously treated non-smallcell lung cancer. N Engl J Med 2005, 353:123-32.

6. Thatcher N, Chang A, Parikh P, Rodrigues Pereira J, Ciuleanu T, von Pawel J, Thongprasert S, Tan EH, Pemberton K, Archer V, Carroll K. Gefitinib plus best supportive care in previously treated patients with refractory advanced non-small-cell lung cancer: results from a randomised, placebo-controlled, multicentre study (Iressa Survival Evaluation in Lung Cancer). Lancet 2005, 366: $1527-37$.

FI000 Factor 6.0 Must Read

Evaluated by Nico van Zandwijk 23 Jan 2006

7. Lynch TJ, Bell DW, Sordella R, Gurubhagavatula S, Okimoto RA, Brannigan BW, Harris PL, Haserlat SM, Supko JG, Haluska FG, Louis DN, Christiani DC, Settleman J, Haber DA: Activating mutations in the epidermal growth factor receptor underlying responsiveness of non-small-cell lung cancer to gefitinib. $N$ Engl J Med 2004, 350:2129-39.

FI000 Factor 10.I Exceptional

Evaluated by William Kaelin 10 May 2004, Joachim Herz 27 May 2004, Michael B Yaffe 3 Jun 2004, Charles Brenner 2 Dec 2004

8. Paez JG, Jänne PA, Lee JC, Tracy S, Greulich H, Gabriel S, Herman P, Kaye FJ, Lindeman N, Boggon TJ, Naoki K, Sasaki H, Fujii Y, Eck MJ, Sellers WR, Johnson BE, Meyerson M: EGFR mutations in lung cancer: correlation with clinical response to gefitinib therapy. Science 2004, 304: 1497-500.

FI000 Factor 10.7 Exceptional

Evaluated by William Kaelin 10 May 2004, Patricia C Weber I 4 May 2004, Joachim Herz 27 May 2004, Charles Streuli I Jul 2004, Alfred Wittinghofer 15 Sep 2004, Charles Brenner 2 Dec 2004

9. van Zandwijk N, Mathy A, Boerrigter L, Ruijter H, Tielen I, de Jong D, Baas P, Burgers S, Nederlof P: EGFR and KRAS mutations as criteria for treatment with tyrosine kinase inhibitors: retroand prospective observations in non-small-cell lung cancer. Ann Oncol 2007, 18:99-103.

10. Mok T, Wu Y, Thongprasert S, Yang C, Chu D, Saijo N, Jiang H, Watkins C, Armour A, Masahiro, Fukuoka M. Phase III, randomised, open-label, first-line study of gefitinib (g) vs carboplatin/paclitaxel (c/p) in clinically selected patients with advanced non-small-cell lung cancer (NSCLC) (IPASS) [abstract]. Ann Oncol 2008, 19:LBA2. 